\title{
Is It Workplace Stress a Trigger for Alcohol and Drug Abuse?
}

\author{
Maria Neyrian de Fatima Fernandes',2, Edilaine Cristina da Silva Gherardi-Donato ${ }^{2}$
}

${ }^{1}$ Federal University of Maranhão (UFMA), Imperatriz, MA, Brazil

${ }^{2}$ Ribeirão Preto School of Nursing, São Paulo University (USP), Ribeirão Preto, SP, Brazil

Email: neyrianfernandes@gmail.com

How to cite this paper: de Fatima Fernandes, M.N. and da Silva Gherardi-Donato, E.C. (2017) Is It Workplace Stress a Trigger for Alcohol and Drug Abuse? Open Journal of Nursing, 7, 435-448.

https://doi.org/10.4236/ojn.2017.73034

Received: January 31, 2017

Accepted: March 28, 2017

Published: March 31, 2017

Copyright $\odot 2017$ by authors and Scientific Research Publishing Inc. This work is licensed under the Creative Commons Attribution International License (CC BY 4.0).

http://creativecommons.org/licenses/by/4.0/

\begin{abstract}
Those workers most vulnerable to pressure tend to suffer from scarce social and personal resources with which to respond adaptively to stress. In this case, the effects of psychoactive substances may exceed the stressed worker's positive expectations. Thus, the aim is to analyze the scientific evidence on the relationship between drug abuse and workplace stress, based on an integrative review of the literature. Data were collected in February 2016 from the databases of the Virtual Health Library and PubMed. The final sample of 16 articles was divided into two categories: alcohol and drugs abuse in professions with high degree of psychosocial hazards and risks, and alcohol and drugs abuse for workplace stress in other professions. A relationship between precarious conditions, the nature of the work and its influence on drug abuse could be seen. However, other variables may strengthen psychoactive drug use as a coping strategy for stress.
\end{abstract}

\section{Keywords}

Work, Psychological Stress, Workplace, Alcoholism, Substance Use Related Disorders, Psychological Adaptation

\section{Introduction}

The human being cannot avoid work. Everything achieved and constructed by humans from pre-history to the present day is the result of labor by diverse individuals. Thus, work can be viewed as one of the pillars of civilization which has been built.

Although work is the basis of the wealth of nations and the source of the individual's financial support, it has also been the source of mental and physical illness. This is due to the characteristics of society that imposes daily situations of 
stress and anxiety on the individual. Anyone who works complains of increased demand and pressure in the workplace, where workers are constantly expected to produce more in less time [1].

Workers, then, see the environment as wearing them down, exhausting their physical and psychological resources and threatening their wellbeing. In this context, stress appears as the individual's reaction to these threats, impelling them to seek to adjust or respond to these conditions that provoke anxiety or fear. This response may be physical, mental or emotional and aims to stabilize internal biological processes and preserve self-esteem [2] [3].

However, a point may be reached at which the organism can no longer bear or support the stressful situation and attempts begin to decrease, manage, control or tolerate the harmful effects of stress. These are known as coping strategies [4] [5].

Coping mechanisms consist of cognitive and problems solving behavior that the individual uses to deal with stress. Coping may be adaptive, through physical activities or socializing with friends and family or non-adaptive, escape strategies, unhealthy behavior such as drug abuse. In general, non-adaptive coping is strongly linked to drug abuse [6] [7].

Studies [8] [9] have shown that there is a close relationship between stress and alcohol and drug abuse. The more stressful events followed by inefficient coping strategies, the greater the vulnerability to drug addiction and abuse. The more negative situations, the greater the risk of using alcohol or drugs as a coping strategy to improve one's mood or distract oneself from disagreeable sensations.

Those individuals most vulnerable to pressure tend to suffer from scarce social and personal resources with which to respond adaptively to stressful situations in the workplace. In these cases, the stressed worker begins to feel positive expectations regarding the effects of psychoactive substances, making them feel more relaxed after use, escaping from the negative emotions of stress. Alcohol possesses a double mechanism, on the one hand, it reduces anxiety and, on the other hand, it acts as a stressor, activating the hypothalamic-pituitary-adrenal axis [8] [10].

The question, then, is: What is the relationship between drug abuse and workplace stress? To assist in elucidating this issue, the following objective was outlined: to analyze the scientific evidence on the relationship between drug abuse and workplace stress.

\section{Materials and Methods}

This is an integrative review of the literature, a broad approach that enables diverse published studies on the topic in question to be integrated. This means that experimental and non-experimental studies can be included to give a complete understanding of the phenomenon in question. The results obtained can create a consistent and comprehensive view of the relevant concepts, theories or problems [11].

The following six steps for the integrative review were followed. The first was 
to identify the topic and select the hypothesis or research question. Next, inclusion and exclusion criteria were defined for the studies/samples or searches in the literature. The third stage was defining the data to be extracted from the selected studies. The fourth evaluated the studies included. Next, the results were interpreted and, finally, at the sixth stage, the review/synthesis of knowledge was presented [11].

The following question was drawn up to guide the research: What is the relationship between drug abuse and coping strategies for workplace stress? Data were collected in February 2016 from the databases included in the Virtual Health Library (VHL) and PubMed through the link "search by DeCs/MeSh descriptors".

The descriptors used were "work", "psychological stress", "alcoholism" and "substance-related disorders" combined through the Boolean operator "AND". Inclusion criteria were: publications between 2010 and 2015, so as to analyze the most up to date publications available in the literature; studies dealing with the topic of stress in workers and drug abuse; workers being study participants; qualitative or quantitative methodological design; and published in Portuguese, English or Spanish. Those studies were excluded which were reviews or discussions; not published in the form of an article (theses or dissertations) and duplicated articles.

The combination of the descriptors "psychological stress", "work" and "alcoholism" produced 94 articles in VHL and 10 in PubMed, the combination of "psychological stress", "work" and "substance-related disorders" produced 115 articles in VHL and 12 in PubMed. Figure 1 synthesizes the search process. The initial sample totaled 231 articles. Of the studies listed, 45 met the inclusion criteria. After applying the exclusion criteria and reading the articles in full, the corpus of this study was composed of 16 articles. Next, the pertinent data were selected for the review and grouped.

Classification of the articles was based on the scientific evidence currently available in the literature, including the levels of the evidence and grades of recommendation to obtain the best results. Level of evidence was classified by the type of study according to the Oxford Centre for Evidence-based Medicine [12]. In reading the articles for the corpus of this study, those with evidence levels up to three were considered.

At level 1, the evidence is from randomized, controlled clinical trials with narrow confidence intervals, or from systematic reviews or meta-analyses of all relevant randomized, controlled clinical trials, or from clinical directives based on systematic reviews of randomized, controlled clinical trials; level 2, evidence derived from historical cohort studies or with segments of compromised cases (at least one well designed randomized controlled clinical trial, but of lower quality) and ecological study; level 3, evidence obtained from well-designed, non-randomized clinical trials (case-control studies), systematic reviews of case control studies [12]. 


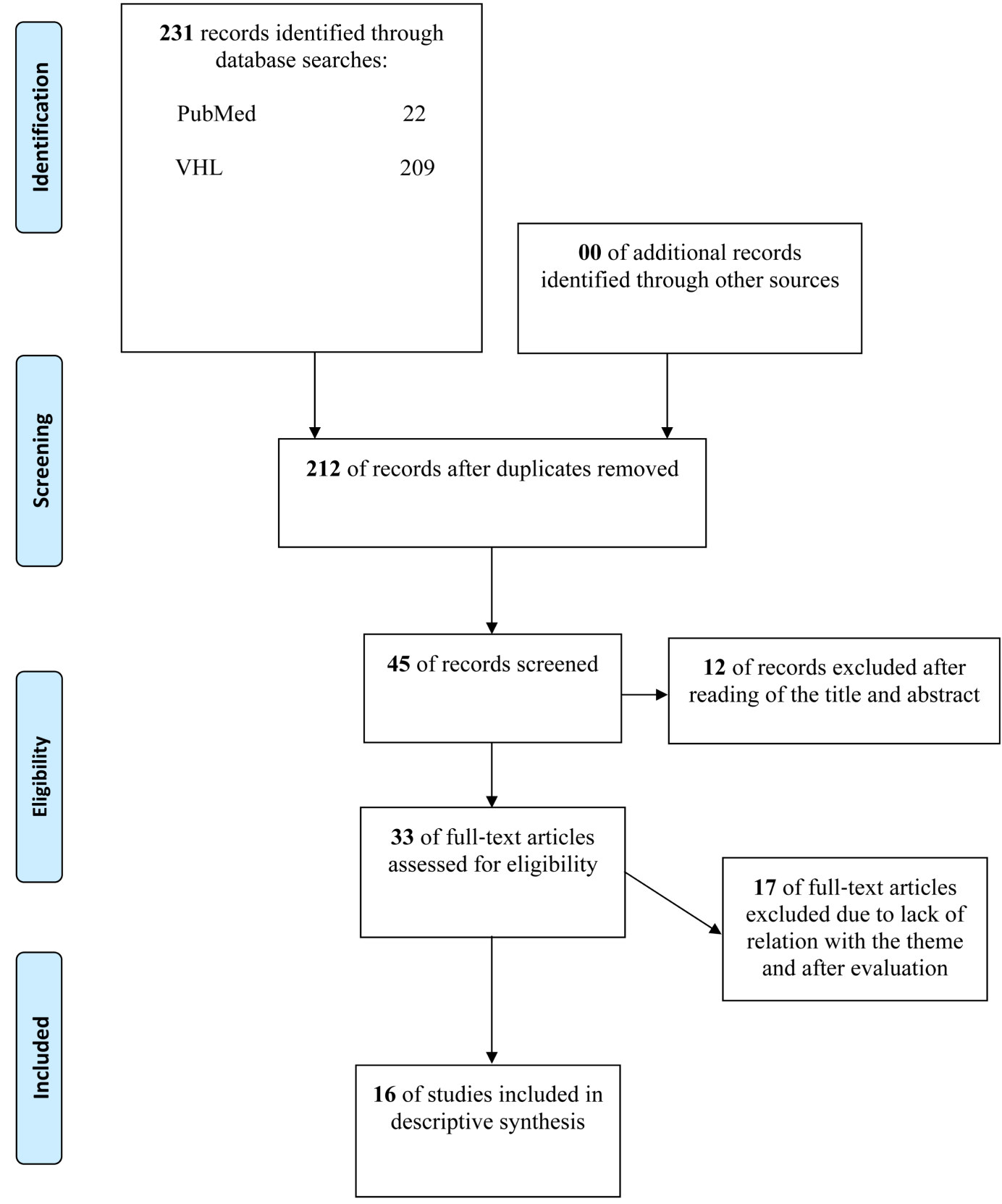

Figure 1. Flow chart of search procedures.

Among the articles making up the final sample, however, there were no randomized clinical trials. Thus, the strength of the evidence of 16 articles was classed as level 2, as the studies were observations of clinical developments or treatment results and two articles as level 3, as they were non-randomized. Thus, the recommendation grade was $\mathrm{B}$, denoting a moderate grade of evidence, being studies that presented important evidence in the outcome.

In order to analyze and interpret the data, they were organized using a previously-prepared data form [13], containing data on the study such as year of publication, authors, type of study, location and population studied; when completed for each article from the sample, the data could be catalogued. Thus, it was easy to 
get an overview of the articles and compare the studies. The articles were divided into two categories of analysis: alcohol and drugs abuse in professions with high degree of psychosocial hazards and risks (8) and alcohol and drugs abuse for workplace stress in other professions (8).

\section{Results}

The articles making up the corpus of this study were written in English, of which two were bilingual (English-Portuguese) and none of them were Spanish. The professionals studied in the 16 articles were separated into two categories. Table 1: professions with high degree of psychosocial hazards and risks and other professions.

Table 2 and Table 3 synthesize the general data on the selected articles. The majority (88\%) were of quantitative design. As for origin, seven (41\%) were conducted in the United States (USA) and the rest in a variety of other countries. Professionals who worked directly in caring for others were analyzed in eight (53\%) of the articles.

\subsection{Alcohol and Drugs Abuse in Professions with High Degree of Psychosocial Hazards and Risks}

All the studies explored the job characteristics and workplace conditions. Both exposure to drugs and difficult working conditions can create psychological distress and cause secondary problems such as drug abuse [14].

Among the prison warders and the police officers studied, their own perception of difficult working conditions and stressful, traumatic day-to-day experiences constituted a risk factor for increased smoking and alcoholism [14] [15]. Such stressful situations can trigger illegal drug use due to constant contact with drugs and drug dealing [15].

Similar working conditions are also found among urban police officers in the USA [16]. In this category, alcohol consumption in the sample (747) studied was considerable; a third of the men and women studied reported consuming large quantities of alcohol on single occasions (bingeing) during the preceding month, a higher proportion than in the general population.

Table 1. (a) Categories of studies according to the professionals' categories.

\begin{tabular}{cc}
\hline Categories of studies & Professionals studied \\
\hline Professions with high degree of psychosocial hazards and risks & Doctors \\
Prison warders & Police officers \\
Bartenders & Fire fighters \\
& Truck drivers \\
& Latino immigrant workers \\
Other professions & Journalists \\
& Construction workers \\
& Civil servants \\
& General workers
\end{tabular}


Table 2. Panorama of the articles by author, title, year of publication, type of study, country of origin and population of the study.

\begin{tabular}{|c|c|c|c|c|c|c|}
\hline Authors & Title & Year & Objective & Type & Country & Population \\
\hline Biron M. & $\begin{array}{l}\text { Work-Related Risk Factors } \\
\text { and Employee Substance Use: } \\
\text { Insights from a Sample of } \\
\text { Israeli Blue-Collar Workers }\end{array}$ & 2011 & $\begin{array}{l}\text { To identify work-related } \\
\text { risk factors and } \\
\text { employee substance use }\end{array}$ & Quantitative & Israel & $\begin{array}{l}569 \\
\text { construction } \\
\text { workers }\end{array}$ \\
\hline $\begin{array}{l}\text { Austin-Ketch } \\
\text { T. L. et al. }\end{array}$ & $\begin{array}{l}\text { Addictions and the Criminal } \\
\text { Justice System, What } \\
\text { Happens on } \\
\text { the Other Side? } \\
\text { Post-Traumatic } \\
\text { Stress Symptoms and } \\
\text { Cortisol Measures in a } \\
\text { Police Cohort }\end{array}$ & 2012 & $\begin{array}{l}\text { To evaluate physiologic and } \\
\text { stress measures in a high-risk } \\
\text { occupation where occupational } \\
\text { exposure to difficult criminal } \\
\text { situations can lead to } \\
\text { physiologic and psychological } \\
\text { health consequences }\end{array}$ & Quantitative & $\begin{array}{l}\text { United } \\
\text { States }\end{array}$ & $\begin{array}{l}100 \text { police } \\
\text { officers }\end{array}$ \\
\hline $\begin{array}{l}\text { Cheng } \\
\text { W. J. }\end{array}$ & $\begin{array}{l}\text { Alcohol Dependence, } \\
\text { Consumption of Alcoholic } \\
\text { Energy Drinks and Associated } \\
\text { Work Characteristics in the } \\
\text { Taiwan Working Population }\end{array}$ & 2012 & $\begin{array}{l}\text { To examine the association } \\
\text { between work and characteristics } \\
\text { and the risk of alcohol dependence } \\
\text { across different employment } \\
\text { types and occupations }\end{array}$ & Quantitative & $\begin{array}{l}\text { Taiwan, } \\
\text { China }\end{array}$ & $\begin{array}{l}22,085 \\
\text { general } \\
\text { workers }\end{array}$ \\
\hline Unrath M. & $\begin{array}{l}\text { Identification of Possible Risk } \\
\text { Factors for Alcohol Use Disorders } \\
\text { among General Practitioners in } \\
\text { Rhineland-Palatinate, Germany }\end{array}$ & 2012 & $\begin{array}{l}\text { To identify possible risk factors } \\
\text { for alcohol use disorders among } \\
\text { general practitioners (GP) working } \\
\text { in the outpatient sector }\end{array}$ & Quantitative & Germany & $\begin{array}{c}2092 \\
\text { doctors }\end{array}$ \\
\hline $\begin{array}{l}\text { Oreskovich R. } \\
\quad \text { M. et al. }\end{array}$ & $\begin{array}{l}\text { Prevalence of Alcohol Use } \\
\text { Disorders among } \\
\text { American Surgeons }\end{array}$ & 2012 & $\begin{array}{l}\text { To determine the point prevalence } \\
\text { of alcohol abuse and dependence } \\
\text { among practicing surgeons }\end{array}$ & Quantitative & $\begin{array}{l}\text { United } \\
\text { States }\end{array}$ & $\begin{array}{c}7197 \\
\text { Surgeons }\end{array}$ \\
\hline Tutenges S. & $\begin{array}{l}\text { Drunken Environments: } \\
\text { a Survey of Bartenders Working } \\
\text { in Pubs, Bars and Nightclubs. } \\
\text { International Journal of } \\
\text { Environmental Research } \\
\text { and Public Health }\end{array}$ & 2013 & $\begin{array}{l}\text { To asses risk factors in the working } \\
\text { environment of bartenders }\end{array}$ & Quantitative & Denmark & $\begin{array}{c}424 \\
\text { bartenders }\end{array}$ \\
\hline $\begin{array}{l}\text { Barros } \\
\text { V. V. et al. }\end{array}$ & $\begin{array}{l}\text { Mental Health Conditions, } \\
\text { Individual and Job } \\
\text { Characteristics and } \\
\text { Sleep Disturbances } \\
\text { among Firefighters }\end{array}$ & 2013 & $\begin{array}{l}\text { To assess the associations between } \\
\text { mental conditions, individual and } \\
\text { job characteristics and sleep } \\
\text { disturbance among firefighters }\end{array}$ & Quantitative & Brazil & $\begin{array}{l}303 \text { fire } \\
\text { fighters }\end{array}$ \\
\hline $\begin{array}{l}\text { Fjeldheim } \\
\text { C. B. et al. }\end{array}$ & $\begin{array}{l}\text { Trauma Exposure, } \\
\text { Posttraumatic Stress } \\
\text { Disorder and the Effect } \\
\text { of Explanatory Variables } \\
\text { in Paramedic Trainees }\end{array}$ & 2014 & $\begin{array}{l}\text { To investigate the type, frequency, } \\
\text { and severity of direct trauma } \\
\text { exposure, posttraumatic stress } \\
\text { symptoms and other } \\
\text { psychopathology amongst } \\
\text { paramedic trainees }\end{array}$ & Quantitative & South Africa & $\begin{array}{c}131 \\
\text { paramedics }\end{array}$ \\
\hline $\begin{array}{l}\text { Collel } \\
\text { E. et al. }\end{array}$ & $\begin{array}{l}\text { Work-Related Stress } \\
\text { Factors Associated with } \\
\text { Problem Drinking: A Study } \\
\text { of the Spanish Working } \\
\text { Population }\end{array}$ & 2014 & $\begin{array}{l}\text { To examine the association between } \\
\text { work-related stress and alcohol } \\
\text { use in a representative sample of the } \\
\text { Spanish working population }\end{array}$ & Quantitative & Spain & $\begin{array}{l}13,005 \\
\text { general work- } \\
\text { ers }\end{array}$ \\
\hline Gavin R. S. & $\begin{array}{c}\text { Association between } \\
\text { Depression, Stress, Anxiety } \\
\text { and Alcohol Use among } \\
\text { Civil Servants }\end{array}$ & 2015 & $\begin{array}{l}\text { To identify depressive symptoms } \\
\text { association with sociodemographic } \\
\text { variables, exposure and dimensions } \\
\text { of occupational stress }\end{array}$ & Quantitative & Brazil & $\begin{array}{l}1239 \text { civil } \\
\text { servants }\end{array}$ \\
\hline
\end{tabular}


Table 3. Panorama of the articles by author, title, year of publication, type of study, country of origin and population of the study.

\begin{tabular}{|c|c|c|c|c|c|c|}
\hline Authors & Title & Year & Objective & Type & Country & Population \\
\hline Bierie D. M. & $\begin{array}{l}\text { The Impact of Prison } \\
\text { Conditions on Staff Well-Being }\end{array}$ & 2010 & $\begin{array}{l}\text { To examine the impact of } \\
\text { prison conditions on staff } \\
\text { well-being (substance use...) }\end{array}$ & Quantitative & United States & $\begin{array}{c}1738 \text { prison } \\
\text { warders }\end{array}$ \\
\hline $\begin{array}{l}\text { Shattell } \\
\text { M. et al. }\end{array}$ & $\begin{array}{l}\text { Occupational Stressors and } \\
\text { the Mental Health of Truckers }\end{array}$ & 2010 & $\begin{array}{l}\text { To report findings on the } \\
\text { occupational stressors and } \\
\text { the mental health of truckers }\end{array}$ & $\begin{array}{l}\text { Quantitative/ } \\
\text { Qualitative }\end{array}$ & United States & $\begin{array}{l}60 \text { truck } \\
\text { drivers }\end{array}$ \\
\hline Negi J. N. & $\begin{array}{l}\text { Identifying Psychosocial } \\
\text { Stressors of Well-Being and } \\
\text { Factors Related to Substance } \\
\text { Use among Latino Day Laborers }\end{array}$ & 2011 & $\begin{array}{l}\text { To identify psychosocial stressors } \\
\text { of well-being and factors } \\
\text { related to substance use } \\
\text { among Latino Day laborers }\end{array}$ & Qualitative & United States & $\begin{array}{l}150 \text { Latino } \\
\text { immigrant } \\
\text { workers }\end{array}$ \\
\hline $\begin{array}{l}\text { Ballenger } \\
\text { J. F. }\end{array}$ & $\begin{array}{l}\text { Patterns and Predictors of } \\
\text { Alcohol Use in Male and } \\
\text { Female Urban Police Officers }\end{array}$ & 2011 & $\begin{array}{l}\text { To examine the drinking } \\
\text { patterns of a large sample of } \\
\text { urban police officer and to identify } \\
\text { specific predictors of alcohol use }\end{array}$ & Quantitative & United States & $\begin{array}{l}747 \text { police } \\
\text { officers }\end{array}$ \\
\hline Buchanan M. & $\begin{array}{l}\text { Coping with Traumatic } \\
\text { Stress in Journalism: } \\
\text { A Critical Ethnographic Study }\end{array}$ & 2011 & $\begin{array}{l}\text { To identify the coping strategies } \\
\text { used to buffer the effects of being } \\
\text { exposed to trauma and disaster } \\
\text { events and work-related stress }\end{array}$ & Qualitative & Canada & $\begin{array}{c}31 \\
\text { journalists }\end{array}$ \\
\hline Mezuk B. & $\begin{array}{l}\text { Job Strain, Depressive Symptoms, } \\
\text { and Drinking Behavior among } \\
\text { Older Adults: Results from the } \\
\text { Health and Retirement Study }\end{array}$ & 2011 & $\begin{array}{l}\text { To examine the relationship } \\
\text { between job strain and two } \\
\text { indicators of mental health, } \\
\text { depression and alcohol misuse, } \\
\text { among currently } \\
\text { employed older adults }\end{array}$ & Quantitative & United States & $\begin{array}{l}2902 \\
\text { working } \\
\text { adults }\end{array}$ \\
\hline
\end{tabular}

It is noteworthy that in this study, the female police officers showed low levels of workplace stress, but high levels of alcohol consumption. This characteristic is attributed to the need to identify oneself with an organization culture for self-affirmation in a male-dominated environment [16].

Even given such results, it is thought that substance abuse among police officers is underreported, as this category perceive alcohol as part of a social event, commonplace and innocent, such as having some beers after work. This type of habit can develop into a coping strategy to deal with the day-to-day tragedies and stress of the profession [15].

Alcohol may also be an element present in the workplace itself, as is the case with bartenders, professionals who make and serve alcoholic drinks to diverse clients. They also live under constant stress because of the risks of verbal aggression and threats. Thus, this work environment presents a risk of developing disorders related to abuse of alcohol and other drugs. One study interviewed 489 bartenders in Denmark; $68.3 \%$ stated they had drunk alcohol while on shift, $40.15 \%$ reported a binge drinking episode during a least one shift within the last month, $17.57 \%$ has drunk 10 or more doses during the last month and $41 \%$ admitted using illegal drugs [17].

The violence at work these professionals experience has been associated with the high levels of stress found, although not with drug use. However, continuous 
exposure to stressors that are out of our control, as in the case of bartenders, can, over time, negatively affect the ability to cope with stress [17].

The case of bartenders reinforces that the norms surrounding alcohol use and that of other drugs and their easy availability in the workplace are basic factors influencing the abuse if these substances [15].

Likewise, high levels of alcohol and greater vulnerability to developing alcohol-related disorders affect health care professionals; $24 \%$ of the 131 emergency services paramedics studied in South Africa abused alcohol, 23\% of the 2092 doctors analyzed in Germany reported drinking alcohol every day and it was found that $18.9 \%$ had suffered from alcohol-related disorders, with females more affected compared to the population in general. In this case, it is believed that the female doctors are exposed to greater stressful factors than other women, to which are allied the challenges of bringing up their own children and the lack of free time [18] [19].

The female surgeons of the 7197 interviewed in the USA also showed greater vulnerability to alcohol abuse or addiction compared with their male colleagues. Another important factor found in this study was the close relationship between alcohol abuse and addiction and the existence of symptoms of depression and burnout syndrome, such as emotional exhaustion, de-personalization and insensitivity [20].

In this study, an association was found between resilience and daily consumption of alcohol which can be considered a coping strategy for at least some of the doctors interviewed [21].

Certain individuals do not possess coping mechanisms sufficient to face dayto-day stressful situations. Thus, they internalize conflicts and emotions, causing a state of agitation and psychological activation, culminating in sleep disturbance. This was the situation found in 51\% of the 303 Brazilian firefighters' studies, with sleep disturbances associated with alcohol abuse and addiction associated with increases in suicidal thoughts [21]. Constant exposure to risk may lead professionals such as prison warders, police officers, fire fighters and doctors, among others, to develop post-traumatic stress.

\subsection{Alcohol and Drugs Abuse for Workplace Stress in Other Professions}

In general, professions are exposed to different types of pressure that can cause stress in susceptible individuals. Each person develops their own strategy for coping with the prolonged effects of stress. However, coping strategies with negative results may cause behavior and mental problems, such as a distraction to avoid thinking of the stressor, which can occur through alcohol or drug abuse, daydreams and insufficient sleep [22].

Professionals in diverse categories, therefore, may view alcohol or drugs as the most accessible and immediate strategy to deal with these demands. For example, truck drivers interviewed in the USA stated that the constant pressure to deliver cargo on time, irrespective of weather or traffic conditions led them to 
resort to drug abuse to stand the pressure and keep active. The preferred drug in this category was crack as it helped deal with the constant loneliness and depression, keeping them alert so as to be able to remain on the road [23].

In contrast, the pressures of the world of work are dealt with better by older professionals, those in their 60s or 70s. Research conducted in the USA with 2902 workers aged over 60 found no association between work pressure and alcoholism. This discrepancy is believed to young workers [24].

In addition to constant pressures at work, flouting labor laws, discrimination, social isolation, instability, undervaluing the professionals and hazardous environments are also determinants of drug abuse, attempting to reduce the effects of these psychosocial stressors. Such situations are faces by truck drivers, Latino workers living illegally in the USA and working men in Taiwan [23] [25] [26] [27].

Of workers in Taiwan, China, those that present the highest prevalence of alcohol addiction (16.8\%) were those doing manual work, other categories at risk included construction workers and miners $(20.3 \%)$, chief executives and politicians (20\%), laborers (15.8\%), journalists and artists (15.4\%) [25]. This prevalence in certain categories may, in some cases, be the result of organizational characteristics such as the culture and behavioral norms in the workplace, as well as easy access to alcohol.

Workers in Spain also showed propensities to drug abuse; of the 13,005 interviewees, $5 \%$ of the males and $2.3 \%$ of the females were classed as heavy drinkers and $19.5 \%$ of the men and $8 \%$ of the women reported bingeing. In the majority of cases, alcohol abuse was associated with work stress factors. It was observed that male heavy drinkers were exposed to hazardous work environments and a lack of social support. Bingeing, in turn, was related to men working in precarious situations [27].

To deal with post-traumatic stress experienced in the workplace routine, 31 Canadian journalists reported resorting to a variety of drugs to overcome the psychological stress. The substances of choice were alcohol, marihuana, hashish, cocaine, crack and heroin. The drugs were used to help "anesthetize" whatever situation might appear in their daily work. The main objective of substance abuse was to suppress or avoid feelings and memories of covering war, homicide or other traumatic events [28].

Among civil servants in Brazil, it was found that anxiety and self-reported problems from alcohol abuse were risk factors for depression. Alcohol use in depressive workers can be seen as a coping strategy [29].

In contrast, $91 \%$ of the 261 workers studies in Israel reported not having drunk alcohol in the month preceding the interview, even when experiencing stress at work. The group studied did not use alcohol or drugs to cope. Culturally, Israel has low per capita alcohol consumption, and a high prevalence of abstinence. It can thus be seen that the company norms and the cultural context also exert considerable influence on the coping strategies chosen to face workplace stress [30]. 


\section{Discussion}

Abuse of alcohol and drugs is more likely to be adopted as a coping strategy for stress when the norms and social context accept alcohol. It represents a serious problem for a significant percentage of the working population $(5 \%-20 \%$ of workers) especially in some sectors and occupations [31]. This can be easily observed in the interaction between controlling the quantity of alcohol consumed in high-risk jobs and the quantity of drugs consumed at social events.

To understand the degree of alcohol use in the workplace it is adopted the concept of standard drinks that means the alcoholic beverages in their containers, that is the same number of units of pure alcohol (approximately $12 \mathrm{~g}$ alcohol). A moderate user would be in an intake of 22 units or more of alcohol a week for men, and 14 or more units a week for women [32]. It is important to highlight that the International Labour Organization (ILO) stated that chronic substance abuse and even moderate use of alcohol and drugs can performance negative effects at the workplace [32].

The results of this study show the relationship between precarious conditions, the nature of the work and its influence on drug abuse, principally alcohol. However, work is not the only risk factor, there are other variables that may also increase alcohol and drug use as coping strategies adopted by workers. Thus, the reasons behind the alcohol and drug abuse triggered by workplace stress are multifactorial.

From the results of this study, it can be seen that cultural factors, such as social acceptance, or lack thereof, of alcohol; social issues, such as the need for female self-affirmation in organizations dominated by male culture; loss of cultural identity, the situation experienced by immigrants; lack of psychological support to deal with pressure and trauma experienced at work all influence the use of psychoactive substances as coping strategies.

In the global context of the impact of psychoactive substance use and abuse within the workplace, public health needs to develop a better understanding of the potential impact. To obtain this better understanding, it is recommended that studies are used that relate to the intervening variables, those that influence the final result, so as to explain how negative experiences of work can lead to psychoactive substance abuse. Moreover, the design of these intervening variables may explain with more consistency the relationship between negative work experiences and alcohol and other drug use [33].

It should be highlighted that the difficulty of evaluating the direct relationship between work stress and consuming psychoactive substances lies in the two-way mechanism of this association. On the one hand, the work may consume alcohol as a way of coping with workplace stress, on the other, alcohol tends to reduce efficiency at work and cause increased workplace stress [34]. Following this line of reasoning, a study involving 140,000 European workers revealed that those who consume large amounts of alcohol and those who abstain are more affected by workplace stress that moderate consumers [34]. 
Of the professionals studies in the articles included in this study, only the bartenders and the journalists reported using illegal drugs, the other only reported using alcohol. This may be because of organizational and cultural issues. This finding shows how psychoactive drug use may be underreported and not reliably reflect these workers' quality of life.

For the prevention of drug abuse at the workplace it is necessary to focus on the identification and rehabilitation of workers with severe alcohol and drug abuse problems. According to the ILO, one of the most challenging issues in combating drug and alcohol abuse in the workplace and in society lies in ignoring the fact that alcohol and drug use is an accepted part of many social and cultural sets. It is difficult to develop a distinction between social drinking of alcohol and the real dangers to health and safety of abusive consumption. It is also problematic in some wine and beer producing countries to discourage workers drinking [35]. For example, in Portugal, in a sample of 100 interviewed, $25 \%$ of workers in the construction and public works sector declared they had drunken alcohol during working hours and most of them stated that they drank it with a meal [36].

Workers who seek treatment and rehabilitation should not be discriminated and should enjoy normal job security and opportunities. Counseling, treatment and rehabilitation programs should be adapted to individual needs. Prevention is a positive approach because emphasize worker health, well-being and safety. Self-assessments can be an important tool to help educate individuals on their own level of substance consumption quantified on a daily or weekly basis [32]. Also, it is imperative to identify individuals' risks and implement protective factors, to promote peer support and to create a healthy workplace environment.

\section{Final Considerations}

From the synthesis of these studies, the relationship between drug abuses as the most used coping mechanism for workplace stress was confirmed. However, the scientific evidence found showed the need to evaluate intervening variables that influenced the use of psychoactive substances so as to minimize the harm of negative experiences at work.

It is still believed to be impossible to draw up a reliable profile of the types of drugs used to cope with workplace stress as, for the majority, illegal drugs may cause more damage to the professional's image. Moreover, the studies did not show a clear methodology for differentiating the nature of the stress identified in their sample, in other words, the measurement of workplace stress cannot be isolated from other sources of stress in the subjects' lives. However, the complexity of the relationship between workplace stress and psychoactive substance consumption as compensatory and codependent mechanisms is evident.

\section{Acknowledgements}

Thanks to the National Department of Drug Policy/SENAD of the Institutional Security Office/Brazil, to the Ribeirão Preto School of Nursing, Universidade de 
São Paulo and World Health Organization Collaborative Center for Developing Nursing.

\section{References}

[1] Abbott, A. (2012) Stress and the City: Urban Decay. Scientists Are Testing the Idea That the Stress of Modern City Life Is a Breeding Ground for Psychosis. Nature, 490, 162-164. https://doi.org/10.1038/490162a

[2] Lazarus, R.S. and Folkman, S. (1984) Stress, Appraisal, And Coping. Amazon Digital Services LLC, New York.

http://www.amazon.com/Stress-Appraisal-Coping-Richard-Lazarusebook/dp/B015 QN2F4Y/ref=mt_kindle?_encoding=UTF8\&me=

[3] Townsend, M.C. (2014) Psychiatric Mental Health Nursing: Concepts of Care in Evidence-Based Practice [e-book]. 8th Edition, F. A. Davis Company, Philadelphia, 527-558.

http://www.amazon.com/Psychiatric-Nursing-Concepts-Evidence-Based-Practice-e book/dp/B00NFXVGSO/ref=sr_1_3?s=digital-text\&ie=UTF8\&qid=1454963017\&sr $=1-3 \&$ keywords $=$ Psychiatric + Mental + Health + Nursing

[4] Folkman, S. (2011) The Oxford Handbook of Stress, Health and Coping. Oxford University Press, New York.

http://www.amazon.com/Oxford-Handbook-Stress-Library-Psychology-ebook/dp/ B00AFY11A4/ref=mt_kindle?_encoding=UTF8\&me=

[5] Puglisi-Allegra, S. and Andolina, D. (2015) Serotonin and Stress Coping. Behavioural Brain Research, 277, 58-67. https://doi.org/10.1016/j.bbr.2014.07.052

[6] Valentino, R.J., Lucki, I. and Van Bockstaele, E. (2010) Corticotropin-Releasing Factor in the Dorsal Raphe Nucleus: Linking Stress Coping and Addiction. Brain Research, 1314, 29-37. https://doi.org/10.1016/j.brainres.2009.09.100

[7] Bowen, P., Edwards, P., Lingard, H. and Cattell, K. (2014) Workplace Stress, Stress Effects, and Coping Mechanisms in the Construction Industry. Journal of Construction Engineering and Management, 140, 1-15. https://doi.org/10.1061/(ASCE)CO.1943-7862.0000807

[8] Hassanbeigi, A., Askari, J., Hassanbeigi, D. and Pourmovahed, Z. (2013) The Relationship between Stress and Addiction. Procedia-Social and Behavioral Sciences, 84, 1333-1340.

[9] Becker, H.C. (2012) Effects of Alcohol Dependence and Withdrawal on Stress Responsiveness and Alcohol Consumption. Alcohol Research: Current Reviews, 34, 448-458.

[10] Gherardi-Donato, E.C.S., Luis, M.A.V. and Corradi-Webster, C.M. (2012) The Relationship between Stress, Alcohol Use, and Work. In: Rossi, A.M., Perrewé, P.L. and Meurs, J.A., Eds., Coping and Prevention ( $A$ Volume in Stress and Quality of Working Life), Information Age Publishing, Charlotte, NC, 60-69.

[11] Souza, M.T., Silva, M.D.D. and Carvalho, R. (2010) Integrative Review: What Is It? How to Do It? Einstein (São Paulo), 8, 102. https://doi.org/10.1590/S1679-45082010RW1134

[12] Oxford (2011) Oxford Centre for Evidence-Based Medicine-Levels of Evidence 2011.

http://www.cebm.net/wp-content/uploads/2014/06/CEBM-Levels-of-Evidence-2.1.p df

[13] Broome, M.E. (2000) Integrative Literature Reviews for the Development of Concepts. In: Rodgers, B.L. and Knafl, K.A., Eds., Concept Development in Nursing: 
Foundations, Techniques and Applications, W. B. Saunders Company, Philadelphia, 231-250.

[14] Bierie, D.M. (2012) The Impact of Prison Conditions on Staff Well-Being. International Journal of Offender Therapy and Comparative Criminology, 56, 81-95. https://doi.org/10.1177/0306624X10388383

[15] Austin-Ketch, T.L., Violanti, J., Fekedulegn, D., Andrew, M.E., Burchfield, C.M. and Hartley, T.A. (2012) Addictions and the Criminal Justice System, What Happens on the Other Side? Post-Traumatic Stress Symptoms and Cortisol Measures in a Police Cohort. Journal of Addictions Nursing, 23, 22-29. https://doi.org/10.3109/10884602.2011.645255

[16] Ballenger, J., Best, S., Metzler, T., Wasserman, D., Mohr, D., Liberman, A., Delucchi, K., Weiss, D., Fagan, J., Waldrop, A. and Marmar, C. (2010) Patterns and Predictors of Alcohol Use in Male and Female Urban Police Officers. American Journal on Addictions, 20, 21-29. https://doi.org/10.1111/j.1521-0391.2010.00092.x

[17] Tutenges, S., Bøgkjær, T., Witte, M. and Hesse, M. (2013) Drunken Environments: A Survey of Bartenders Working in Pubs, Bars and Nightclubs. International Journal of Environmental Research and Public Health, 10, 4896-4906. https://doi.org/10.3390/ijerph10104896

[18] Unrath, M., Letzel, S., Claus, M., Escobar Pinzón, L.C. and Zeeb, H. (2012) Identification of Possible Risk Factors for Alcohol Use Disorders among General Practitioners in Rhineland-Palatinate, Germany. Swiss Medical Weekly, 142, w13664.

[19] Fjeldheim, C.B., Nöthling, J., Pretorius, K., Basson, M., Ganasen, K., Heneke, R., Cloete, K.J. and Seedat, S. (2014) Trauma Exposure, Posttraumatic Stress Disorder and the Effect of Explanatory Variables in Paramedic Trainees. BMC Emergency Medicine, 23, 11.

[20] Oreskovich, M.R., Kaups, K.L., Balch, C.M., Hanks, J.B., Satele, D., Sloan, J., Meredith, C., Buhl, A., Dyrbye, L.N. and Shanafelt, T.D. (2012) Prevalence of Alcohol Use Disorders among American Surgeons. Archives of Surgery, 147, 168-174.

[21] Barros, V.V., Martins, L.F., Saitz, R., Bastos, R.R. and Ronzani, T.M. (2013) Mental Health Conditions, Individual and Job Characteristics and Sleep Disturbances among Firefighters. Journal of Health Psychology, 18, 350-358.

https://doi.org/10.1177/1359105312443402

[22] Collin, S. (2008) Statuary Social Workers: Stress, Job Satisfaction, Coping, Social Support and Individual Differences. The British Journal of Social Work, 38, 1173 1193. https://doi.org/10.1093/bjsw/bcm047

[23] Shattell, M., Apostolopoulos, Y., Sönmez, S. and Griffin, M. (2010) Occupational Stressors and the Mental Health of Truckers. Issues in Mental Health Nursing, 31, 561-568. https://doi.org/10.3109/01612840.2010.488783

[24] Mezuk, B., Bohnert, A.S.B., Ratliff, S. and Zivin, K. (2011) Job Strain, Depressive Symptoms, and Drinking Behavior among Older Adults: Results From the Health and Retirement Study. The Journals of Gerontology Series B: Psychological Sciences and Social Sciences, 66B, 426-434. https://doi.org/10.1093/geronb/gbr021

[25] Negi, N.J. (2011) Identifying Psychosocial Stressors of Well-Being and Factors Related to Substance Use among Latino Day Laborers. Journal of Immigrant and Minority Health, 13, 748-755. https://doi.org/10.1007/s10903-010-9413-x

[26] Cheng, W.-J., Cheng, Y., Huang, M.-C. and Chen, C.-J. (2012) Alcohol Dependence, Consumption of Alcoholic Energy Drinks and Associated Work Characteristics in the Taiwan Working Population. Alcohol and Alcoholism, 47, 372-379.

https://doi.org/10.1093/alcalc/ags034 
[27] Colell, E., Sánchez-Niubò, A., Benavides, F.G., Delclos, G.L. and Domingo-Salvany, A. (2014) Work-Related Stress Factors Associated with Problem Drinking: A Study of the Spanish Working Population. American Journal of Industrial Medicine, 57, 837-846. https://doi.org/10.1002/ajim.22333

[28] Buchanan, M. and Keats, P. (2011) Coping with Traumatic Stress in Journalism: A Critical Ethnographic Study. International Journal of Psychology, 46, 127-135. https://doi.org/10.1080/00207594.2010.532799

[29] Gavin, R.S., Reisdorfer, E., da Silva Gherardi-Donato, E.C., dos Reis, L.N. and Zanetti, A.C.G. (2015) Associação entre depressão, estresse, ansiedade e uso de álcool entre servidores públicos. SMAD. Revista Eletrônica Saúde Mental Álcool e Drogas, 11, 2-9.

[30] Biron, M., Bamberger, P.A. and Noyman, T. (2011) Work-Related Risk Factors and Employee Substance Use: Insights from a Sample of Israeli Blue-Collar Workers. Journal of Occupational Health Psychology, 16, 247-263. https://doi.org/10.1037/a0022708

[31] Corral, A., Durán, J. and Isusi, I. (2012) Use of Alcohol and Drugs at the Workplace. European Foundation for the Improvement of Living and Working Conditions, 1-49.

[32] International Labour Organization (ILO) (2003) Alcohol and Drug Problems at Work: The Shift to Prevention. International Labour Organization.

[33] Frone, M. (2014) Chronic Work Conditions and Employee Alcohol Use: Testing the Mediating Role of Work Rumination. Alcoholism-Clinical And Experimental Research, 38, 263.

[34] Heikkilä, K., Nyberg, S.T., Fransson, E.I., Alfredsson, L., De Bacquer, D., Bjorner, J.B., Bonenfant, S., Borritz, M., Burr, H., Clays, E., et al. (2012) Job Strain and Alcohol Intake: A Collaborative Meta-Analysis of Individual-Participant Data from 140,000 Men and Women. PLoS ONE, 7, e40101. https://doi.org/10.1371/journal.pone.0040101

[35] International Labour Organization (ILO) (2017) A Consensual Approach to Workplace Substance Abuse: From Rehabilitation to Prevention. Prevention of Alcohol and Drugs use in the Workplace, 1996-2017.

http://www.ilo.org/safework/areasofwork/workplace-health-promotion-and-well-be ing/WCMS_108398/lang--en/index.htm

[36] Arezes, P.M. and Bizarro, M. (2011) Alcohol Consumption and Risk Perception in the Portuguese Construction Industry. Open Occupational Health \& Safety Journal, 3, 10-17. https://doi.org/10.2174/1876216601103010010

\author{
Abbreviations \\ ILO: International Labour Organization \\ VHL: Virtual Health Library \\ USA: United States of America
}


Submit or recommend next manuscript to SCIRP and we will provide best service for you:

Accepting pre-submission inquiries through Email, Facebook, LinkedIn, Twitter, etc. A wide selection of journals (inclusive of 9 subjects, more than 200 journals)

Providing 24-hour high-quality service

User-friendly online submission system

Fair and swift peer-review system

Efficient typesetting and proofreading procedure

Display of the result of downloads and visits, as well as the number of cited articles Maximum dissemination of your research work

Submit your manuscript at: http://papersubmission.scirp.org/

Or contact ojn@scirp.org 